Research Article

\title{
Effect of PWHT on the Carbon Migration and Mechanical Properties of 2205DSS-Q235 LBW Joint
}

\author{
Fujun Cao $\mathbb{D}^{1}$ and Chengchao Du $\mathbb{D}^{2}$ \\ ${ }^{1}$ Seksun Technology (Suzhou) Co.,Ltd, Suzhou 215100, China \\ ${ }^{2}$ School of Power and Mechanical Engineering, Wuhan University, Wuhan 430072, China \\ Correspondence should be addressed to Chengchao Du; lanshanchimu@126.com
}

Received 2 June 2018; Revised 7 September 2018; Accepted 6 November 2018; Published 2 December 2018

Guest Editor: Marek Smaga

Copyright (C) 2018 Fujun Cao and Chengchao Du. This is an open access article distributed under the Creative Commons Attribution License, which permits unrestricted use, distribution, and reproduction in any medium, provided the original work is properly cited.

\begin{abstract}
The effect of postweld heat treatment (PWHT) on the carbon migration and mechanical properties of the 2205DSS-Q235 laser beam welding (LBW) joint was investigated. The carbon-rich zone (CRZ) and carbon-depleted zone (CDZ) generated at the welding seam/Q235 (WS-Q235) interface as the carbon migration occurred after heat-treated at $600^{\circ} \mathrm{C}, 700^{\circ} \mathrm{C}$, and $800^{\circ} \mathrm{C}$ for $1 \mathrm{~h}$. The softening was found in the CDZ. Only the CRZ in joints heat-treated at $800^{\circ} \mathrm{C}$ was hardened because of the retaining of highcarbon untempered martensite. The thick $\mathrm{CDZ}$ in joints heat-treated at $700^{\circ} \mathrm{C}$ and $800^{\circ} \mathrm{C}$ contributed to the tensile fracture and the low elongation. The strength of the joint was roughly determined by the hardness of the fracture zone.
\end{abstract}

\section{Introduction}

Dissimilar steel welding is common in pressure vessel manufacturing. Dissimilar joints, such as martensitic steel/ martensitic steel [1], martensitic steel/austenitic steel [2-4], and Ni-based superalloy/austenitic steel [5], have been widely investigated. Among these dissimilar joints, carbon migration from carbon steel to high-Cr weld metal (WM) was usually observed. The carbon migration was in uphill diffusion, as the carbon atom continuously diffusing from the low-carbon steel to the CRZ. Many investigations revealed that the uphill diffusion depended on the higher $\mathrm{Cr}$ concentration in the WM [6-8]. Cr atoms combine with the carbon atoms from carbon steel and generate $\mathrm{M}_{23} \mathrm{C}_{6}$ and $\mathrm{M}_{7} \mathrm{C}_{3}$ (M stands for $\mathrm{Cr}$, $\mathrm{Fe}$, and $\mathrm{Mn}$ ) in the $\mathrm{WM}$ near the $\mathrm{WM} /$ carbon steel interface [6]. Therefore, the CRZ forms in the WM near the WM/ carbon steel interface. As the loss of carbon atom near the interface occurs, the CDZ generates in the carbon steel near the WM/carbon steel interface. Mas et al. [6] indicated that the diffusion of carbon atom to high-Cr region was driven by the high chemical potential gradient across the interface.

The generation of CDZ in the dissimilar joint always contributed to the change in mechanical properties. Ming et al. [9] employed Inconel $52 \mathrm{M}$ as the transition layer to join the 316L and SA508 steel. They found that the hardest area was in the 1 st layer of $52 \mathrm{Mb}$ just adjacent to the SA508-52Mb interface due to the CRZ. The CDZ just adjacent to the fusion boundary had the lowest hardness. Sarikka et al. [10] found that the PWHT improved the carbon migration, thus resulting in the wider and softer CDZ compared to the as-welded state in the SA508-Alloy 52 interface. $\mathrm{Wu}$ et al. [11] observed that the CDZ in the $9 \% \mathrm{Cr}$ fusion zone induced the fracture during the highcycle fatigue test at $470^{\circ} \mathrm{C}$. It can be concluded that the generation of $\mathrm{CDZ}$ contributed to the poor performance of the dissimilar joint.

Laser beam welding (LBW) provides outstanding characteristics of high energy density and high welding speed [12]. It contributes to the rapid joining of aluminum alloys [13, 14], magnesium alloys [15, 16], and steel [17, 18]. In our previous study, 2205DSS and Q235 steel with a thickness of $6.5 \mathrm{~mm}$ was joined using LBW [19]. In order to improve the toughness of the LBW joint, the PWHT process was conducted. After the PWHT process, CDZ and CRZ were generated as the carbon migration [20]. In this investigation, the mechanical properties of the joints with 
different PWHT processes were investigated. Based on these results, the effect of PWHT on the carbon migration and mechanical properties were derived.

\section{Materials and Experiments}

The 2205DSS and Q235 plates with a thickness of $6.5 \mathrm{~mm}$ were joined using LBW without filler metal. The power of the laser beam was $3.7 \mathrm{~kW}$. The defocusing distance was $0 \mathrm{~mm}$. The welding speed was $1.2 \mathrm{~m} / \mathrm{min}$. The shielded gas was Ar gas with a flow rate of $25 \mathrm{~L} / \mathrm{min}$. The joints were heat-treated at $500^{\circ} \mathrm{C}, 600^{\circ} \mathrm{C}, 700^{\circ} \mathrm{C}$, and $800^{\circ} \mathrm{C}$ for $1 \mathrm{~h}$. The cross-sectional specimen of the weld joint perpendicular to the WD was prepared using an electrical discharge machine (EDM). The specimens were mechanically polished using waterproof $\mathrm{SiC}$ emery papers of up to 7000 grit and mirror polished using a colloidal $\mathrm{Al}_{2} \mathrm{O}_{3}(100 \mathrm{~nm})$ suspension. The mirror-polished specimens were then etched using a solution consisting of $\mathrm{HNO}_{3}(40 \mathrm{vol} \%)+\mathrm{C}_{2} \mathrm{H}_{5} \mathrm{OH}$ for $\sim 5 \mathrm{~s}$ and subjected to the optical microscopy (OM, Zeiss Axio Scope A1) observation, scanning electron microscopy (SEM, MIRA3 LMH) observation, and electron probe microanalysis (EPMA, EPMA1600). The tests of SEM and EPMA were under the secondary electron imaging (SEI) mode. For the electron backscatter diffraction (EBSD, MIRA3 LMH + Oxford) observation, the specimens were mechanically polished in a similar manner and then electropolished in a solution consisting of $10 \mathrm{vol} \% \%$ perchloric acid and $90 \mathrm{vol} . \%$ ethanol at $20 \mathrm{~V}$ for $\sim 10 \mathrm{~s}$ at room temperature. The step size of $1 \mu \mathrm{m}$ was set for EBSD observation. The results from the EBSD were analyzed using Channel 5 software. The films with a diameter of $3 \mathrm{~mm}$ were prepared using a twin-jet electropolishing device and observed using a transmission electron microscope (TEM, JEM-2100).

The microhardness was measured using a mircohardness tester with a load of $200 \mathrm{~g}$ and a dwell time of $5 \mathrm{~s}$. The tensile test was conducted using a tensile machine with the help of fixture. The tensile speed was $100 \mu \mathrm{m} / \mathrm{min}$.

The schematic of the joint is shown in Figure 1(a). The cross section of the joint is shown in Figure 1(b). A narrow WS (approximately $1 \mathrm{~mm}$ ) was observed from Figure 1(b). The chemical compositions of the WS, Q235 BM, and 2205DSS BM are listed in Table 1. The interface of the WS/ Q235 is shown in Figure 1(c). The structure of the tensile sample is shown in Figure 1(d). The tensile sample and fixture are shown in Figures 1(d) and 1(e). The fractured samples are shown in Figure 1(f).

\section{Results and Discussion}

\subsection{Microstructure after PWHT}

3.1.1. WS Evolution. The microstructure of WS is shown in Figure 2 [20]. The microstructure of the as-welded WS is shown in Figures 2(a) and 2(g). High dislocation density can be observed in Figure 2(g). Moreover, a small amount of retained austenite is observed in Figure 2(g). The microstructure of as-welded WS was mainly untempered martensite $[19,20]$.
The phase diagram of the WS (Figure 2(f)) was calculated using JMatPro software. According to the phase fraction of the WS, the $\mathrm{Ac}_{1}$ temperature $\left(621^{\circ} \mathrm{C}\right)$ and $\mathrm{Ac}_{3}$ temperature $\left(772^{\circ} \mathrm{C}\right)$ were derived. In this investigation, the PWHT temperatures of $500^{\circ} \mathrm{C}$ and $600^{\circ} \mathrm{C}$ were lower than the $\mathrm{Ac}_{1}$ temperature. The untempered martensite would become tempered martensite. The microstructures of the WS heattreated at $500^{\circ} \mathrm{C}$ and $600^{\circ} \mathrm{C}$ are shown in Figures 2(b) and 2(c). The martensitic lath was clearer. The microstructure of the WS heat-treated at $600^{\circ} \mathrm{C}$ is revealed in Figure 2(h). It could be observed that the $(\mathrm{Cr}, \mathrm{Fe})_{23} \mathrm{C}_{6}$ particles precipitated in the martensitic lath boundary. The high dislocation density disappeared. The subgrain was observed. Moreover, the dislocation density declined.

When the PWHT temperature was increased to $700^{\circ} \mathrm{C}$, part of martensite transformed into the $\gamma$ phase. After cooled to the room temperature, the $\gamma$ phase became the untempered martensite again. The martensite, which did not transformed into the $\gamma$ phase, became the deeply tempered martensite during the PWHT. Therefore, the microstructure of the WS heat-treated at $700^{\circ} \mathrm{C}$ was consisted of untempered martensite and tempered martensite.

When the PWHT temperature was increased to $800^{\circ} \mathrm{C}$, the martensite totally transformed into the $\gamma$ phase which can be observed from Figure 2(f). After cooled to the room temperature, the $\gamma$ phase became the untempered martensite again. From the microstructure in Figure 2(e), the martensitic lath could not be clearly observed. It meant that carbide did not precipitate. The TEM image of the WS heattreated at $800^{\circ} \mathrm{C}$ is revealed in Figure $2(\mathrm{i})$. The $(\mathrm{Cr}, \mathrm{Fe})_{23} \mathrm{C}_{6}$ particles on the grain boundaries disappeared. The martensitic lath with a high dislocation density was observed again.

From the above results and discussion, the untempered martensite transformed into the tempered martensite after heat-treated at $500^{\circ} \mathrm{C}$ and $600^{\circ} \mathrm{C}$. The WS heat-treated at $700^{\circ} \mathrm{C}$ consisted of tempered martensite and part of untempered martensite. The WS heat-treated at $800^{\circ} \mathrm{C}$ was total untempered martensite.

3.1.2. Interface Evolution. The WS-Q235 interfaces after heat-treated are shown in Figure 3 [20]. From Figure 3(a), the carbon migration was not observed in the WS-Q235 interface heat-treated at $500^{\circ} \mathrm{C}$. When the PWHT temperature was increased to $600^{\circ} \mathrm{C}, \mathrm{CRZ}$ and $\mathrm{CDZ}$ were observed. When the PWHT temperature was raised to $700^{\circ} \mathrm{C}, \mathrm{CRZ}$ and thick CDZ were observed (Figures 3(c) and 3(f)). However, when the PWHT temperature was increased to $800^{\circ} \mathrm{C}$, only the CDZ was observed (Figures 3(d) and 3(e)). Moreover, the thickness of the $\mathrm{CDZ}$ heat-treated at $800^{\circ} \mathrm{C}$ was smaller than that heat-treated at $700^{\circ} \mathrm{C}$.

In order to observe the CRZ in the WS-Q235 interface heat-treated at $800^{\circ} \mathrm{C}$, the cross section was etched by $\mathrm{FeCl}_{3}+\mathrm{HCl}$ solution again. The optical image of the WSQ235 interface is shown in Figure 3(g). The CRZ was distinguished.

The formation of the CDZ and CRZ was attributed to the $\mathrm{Cr}$ in the WS $[6-8,21]$. During the PWHT process of 


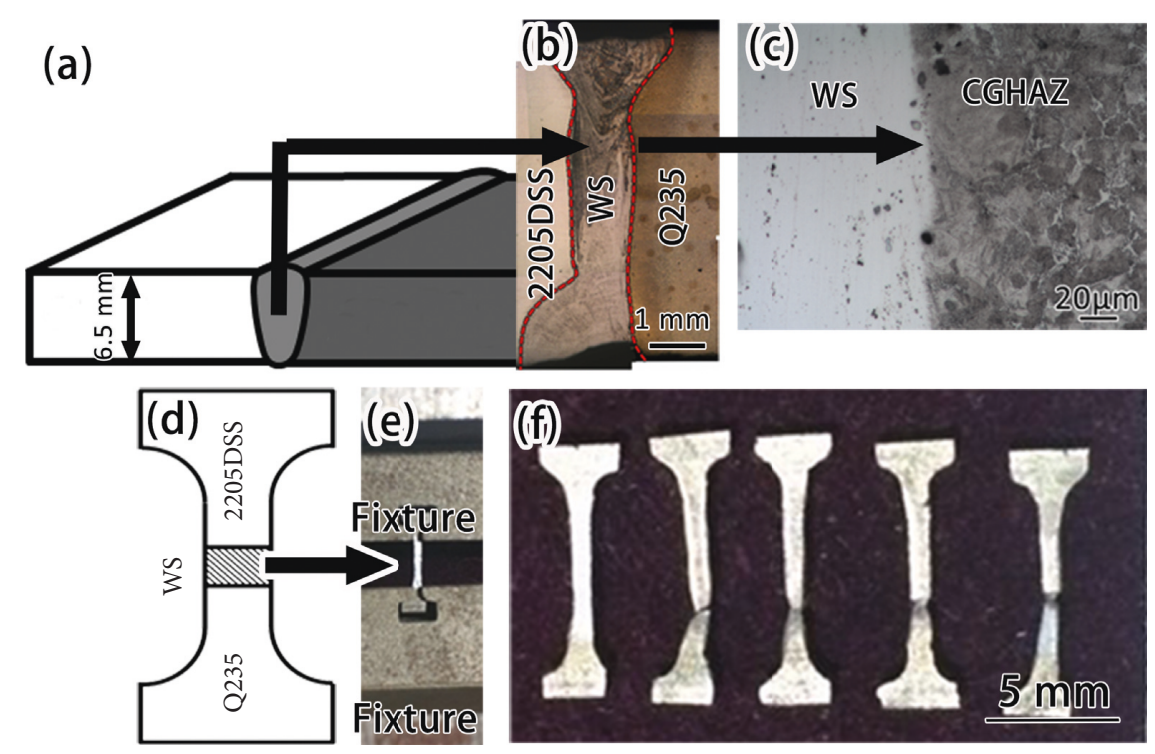

Figure 1: (a) Schematic of the joint; (b) cross section of the joint; (c) microstructure of the WS-Q235 interface; (d) structure of the tensile sample; (e) fixture of the tensile sample; (f) fractured tensile samples.

TABLE 1: Chemical compositions of WS, Q235 BM, and 2205DSS BM (wt.\%).

\begin{tabular}{lcccccccccc}
\hline Materials & $\mathrm{C}$ & $\mathrm{Si}$ & $\mathrm{Mn}$ & $\mathrm{Ni}$ & $\mathrm{Cr}$ & $\mathrm{Mo}$ & $\mathrm{N}$ & $\mathrm{S}$ & $\mathrm{P}$ & $\mathrm{Fe}$ \\
\hline WS & 0.107 & 0.350 & 0.823 & 2.067 & 8.800 & 1.186 & 0.055 & 0.013 & 0.03 & Bal. \\
Q235 & 0.16 & 0.21 & 0.55 & - & - & - & - & 0.020 & 0.030 & Bal. \\
2205DSS & 0.025 & 0.570 & 1.250 & 5.300 & 22.570 & 3.040 & 0.14 & 0.002 & 0.030 & Bal. \\
\hline
\end{tabular}

2205DSS-Q235 joint, the carbon atom continuously migrated from the Q235 BM to the WS. It combined with the $\mathrm{Cr}$ and $\mathrm{Fe}$ atoms and contributed to the generation of the $(\mathrm{Cr}, \mathrm{Fe})_{23} \mathrm{C}_{6}$ carbide in WS. Therefore, CDZ and CRZ generated in Q235 BM and WS, respectively. The thickness of CDZ and CRZ as a function of PWHT temperature is revealed in Figure 3(h). The CDZ thickened as the increase of temperature when the PWHT temperature was below $700^{\circ} \mathrm{C}$. However, when the PWHT temperature was raised to $800^{\circ} \mathrm{C}$, the thickness of the CDZ declined to approximately $130 \mu \mathrm{m}$. The rapid thickening of the CRZ is also marked in Figure 3(h).

3.1.3. Carbon-Depleted Zone Evolution. The $\mathrm{Ac}_{1}$ temperature of Q235 BM was approximately $710^{\circ} \mathrm{C}$ as shown in Figure 4. Therefore, when the PWHT temperature was $500^{\circ} \mathrm{C}, 600^{\circ} \mathrm{C}$, and $700^{\circ} \mathrm{C}$, the phase in the $\mathrm{CDZ}$ was mainly the $\alpha$-Fe phase. The generation of CDZ mainly relied on the migration of carbon atom from Q235 to WS. Therefore, the thickness of CDZ depended on the diffusion rate of carbon atom. When the temperature increased (below $710^{\circ} \mathrm{C}$ ), the carbon migration gradually accelerated. Therefore, the thickness of the CDZ increased as the increase of PWHT temperature.

When the temperature was $800^{\circ} \mathrm{C}$, the $\mathrm{CDZ}$ consisted of $\alpha$-Fe and $\gamma$-Fe as shown in Figure 4 . At the early stage of the $\mathrm{PWHT}$ at $800^{\circ} \mathrm{C}$, the carbon concentration of Q235 near the WS/Q235 interface was 0.16 wt.\%. The volume fraction of
$\gamma$-Fe was $54 \%$. However, when the PWHT time extended to $1 \mathrm{~h}$, the carbon concentration of CDZ was only approximately 0.087 wt.\% (from EPMA result). According to Figure 4 , the volume fraction of $\gamma$-Fe was $31 \%$ after heat-treated for $1 \mathrm{~h}$. Huang et al. [21] indicated that the $\gamma$-Fe in the CDZ slowed the migration of carbon atom. Therefore, the CDZ in the joint heat-treated at $800^{\circ} \mathrm{C}$ was thinner than that heattreated at $700^{\circ} \mathrm{C}$.

The grain orientation (in the $X$ direction) of WS/Q235 interface heat-treated at $700^{\circ} \mathrm{C}$ and $800^{\circ} \mathrm{C}$ is shown in Figure 5 . The columnar $\alpha$-Fe grain with a straight grain boundary was observed in the $\mathrm{CDZ}$ heat-treated at $700^{\circ} \mathrm{C}$. However, the part of grain boundaries of the $\alpha$-Fe grain in the $\mathrm{CDZ}$ heat-treated at $800^{\circ} \mathrm{C}$ was not straight anymore as indicated in Figure 5(b). It should be attributed to the transformation from $\gamma$-Fe to $\alpha$-Fe when the joint cooled from $800^{\circ} \mathrm{C}$ to room temperature. The grain boundary of $\gamma$-Fe and $\alpha$-Fe at $800^{\circ} \mathrm{C}$ should also be the straight. When the temperature declined, the $\alpha$-Fe grains would nucleate in the grain boundary. The prior austenitic grain was partitioned by the new $\alpha$-Fe grains. Therefore, the zigzag grain boundaries generated after heat-treated at $800^{\circ} \mathrm{C}$.

The difference in the $\mathrm{Fe}_{3} \mathrm{C}$ particle after heat-treated at $700^{\circ} \mathrm{C}$ and $800^{\circ} \mathrm{C}$ should also be discussed in this investigation. The $\mathrm{Fe}_{3} \mathrm{C}$ particle is indicated in Figures 5(c) and 5(d). It can be observed from Figures 5(c) and 5(d) that the $\mathrm{Fe}_{3} \mathrm{C}$ particle in the $\mathrm{CDZ}$ heat-treated at $700^{\circ} \mathrm{C}$ was less than that heat-treated at $800^{\circ} \mathrm{C}$. The $\alpha$-Fe phase in the $\mathrm{CDZ}$ heattreated at $700^{\circ} \mathrm{C}$ exhibited a smaller solubility for carbon 

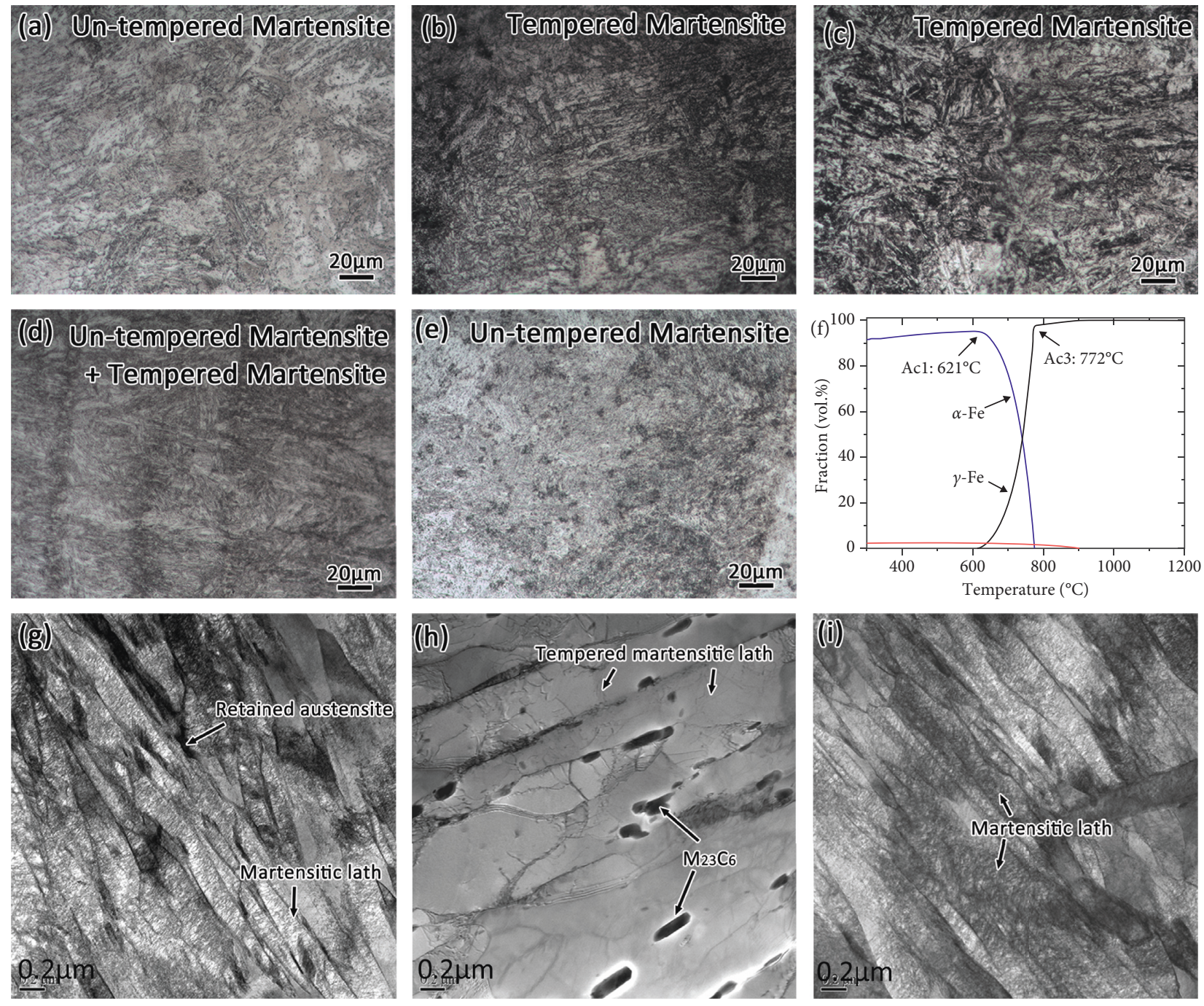

Figure 2: Microstructure and phase diagram of WS: (a, g) as-welded; (b) heat-treated at $500^{\circ} \mathrm{C},(\mathrm{c}, \mathrm{h})$ heat-treated at $600^{\circ} \mathrm{C},(\mathrm{d})$ heat-treated at $700^{\circ} \mathrm{C}$, (e, i) heat-treated at $800^{\circ} \mathrm{C}$, (f) phase diagram.

atoms when compared with that heat-treated at $800^{\circ} \mathrm{C}$. Moreover, the $\gamma$-Fe phase in the $\mathrm{CDZ}$ at $800^{\circ} \mathrm{C}$ exhibited a larger solubility for carbon atoms when compared with the $\alpha$-Fe phase at $700^{\circ} \mathrm{C}$. Therefore, more carbon atoms were dissolved in the $\mathrm{CDZ}$ at $800^{\circ} \mathrm{C}$. After cooled to room temperature from $800^{\circ} \mathrm{C}$, more $\mathrm{Fe}_{3} \mathrm{C}$ particles precipitated from the CDZ.

3.1.4. Carbon-Rich Zone Evolution. The $\mathrm{Ac}_{1}$ and $\mathrm{Ac}_{3}$ temperatures of the WS as a function of carbon concentration are shown in Figure 6(a). From Figure 6(a), the microstructure of the WS at $700^{\circ} \mathrm{C}$ consisted of $\alpha$-Fe and $\gamma$-Fe. The volume fraction of the $\gamma$-Fe in the as-welded WS was $21 \%$. When heat-treated at $700^{\circ} \mathrm{C}$ for $1 \mathrm{~h}$, the carbon concentration of the CRZ was approximately $0.47 \mathrm{wt} \%$ (from EPMA). The volume fraction of the $\gamma$-Fe was $17 \%$ from Figure 6(a). The matrix of WS became pure $\gamma$-Fe at $800^{\circ} \mathrm{C}$ as shown in Figure 6(a).

$(\mathrm{Cr}, \mathrm{Fe})_{23} \mathrm{C}_{6}$ carbide would generate at $700^{\circ} \mathrm{C}$ and $800^{\circ} \mathrm{C}$. Its volume fraction is shown in Figure 6(b). The carbon concentration of the $\mathrm{CRZ}$ in the joint heat-treated at $800^{\circ} \mathrm{C}$ was 0.22 wt.\% (from EPMA). The volume fraction of the $(\mathrm{Cr}, \mathrm{Fe})_{23} \mathrm{C}_{6}$ carbide at $800^{\circ} \mathrm{C}$ was only $3.3 \%$. However, the volume fraction of $(\mathrm{Cr}, \mathrm{Fe})_{23} \mathrm{C}_{6}$ carbide at $700^{\circ} \mathrm{C}$ reached $8.9 \%$.

From the carbon concentration of the CRZ in the joint heat-treated at $700^{\circ} \mathrm{C}$ and $800^{\circ} \mathrm{C}$, the wider CRZ with a lower carbon concentration was found in the joint heat-treated at $800^{\circ} \mathrm{C}$. The formation of the wider CRZ relied on the longdistance diffusion of carbon atom. At $800^{\circ} \mathrm{C}$, the grain boundary contained less $(\mathrm{Cr}, \mathrm{Fe}){ }_{23} \mathrm{C}_{6}$ carbide. The diffusion of the carbon atom along the grain boundary at $800^{\circ} \mathrm{C}$ was easier than that at $700^{\circ} \mathrm{C}$ as the weaker hindering effect of $(\mathrm{Cr}, \mathrm{Fe})_{23} \mathrm{C}_{6}$. Therefore, the wider $\mathrm{CRZ}$ was generated at $800^{\circ} \mathrm{C}$.

The $\mathrm{CRZ}$ in the joint heat-treated at $600^{\circ} \mathrm{C}$ consisted of tempered martensite and $(\mathrm{Cr}, \mathrm{Fe})_{23} \mathrm{C}_{6} \cdot(\mathrm{Cr}, \mathrm{Fe})_{23} \mathrm{C}_{6}$ came from two sources. The first was the carbon from the WS. The second was the carbon from the Q235 BM. The CRZ in the joint heat-treated at $700^{\circ} \mathrm{C}$ consisted of tempered martensite, untempered martensite, and $(\mathrm{Cr}, \mathrm{Fe})_{23} \mathrm{C}_{6}$. The 

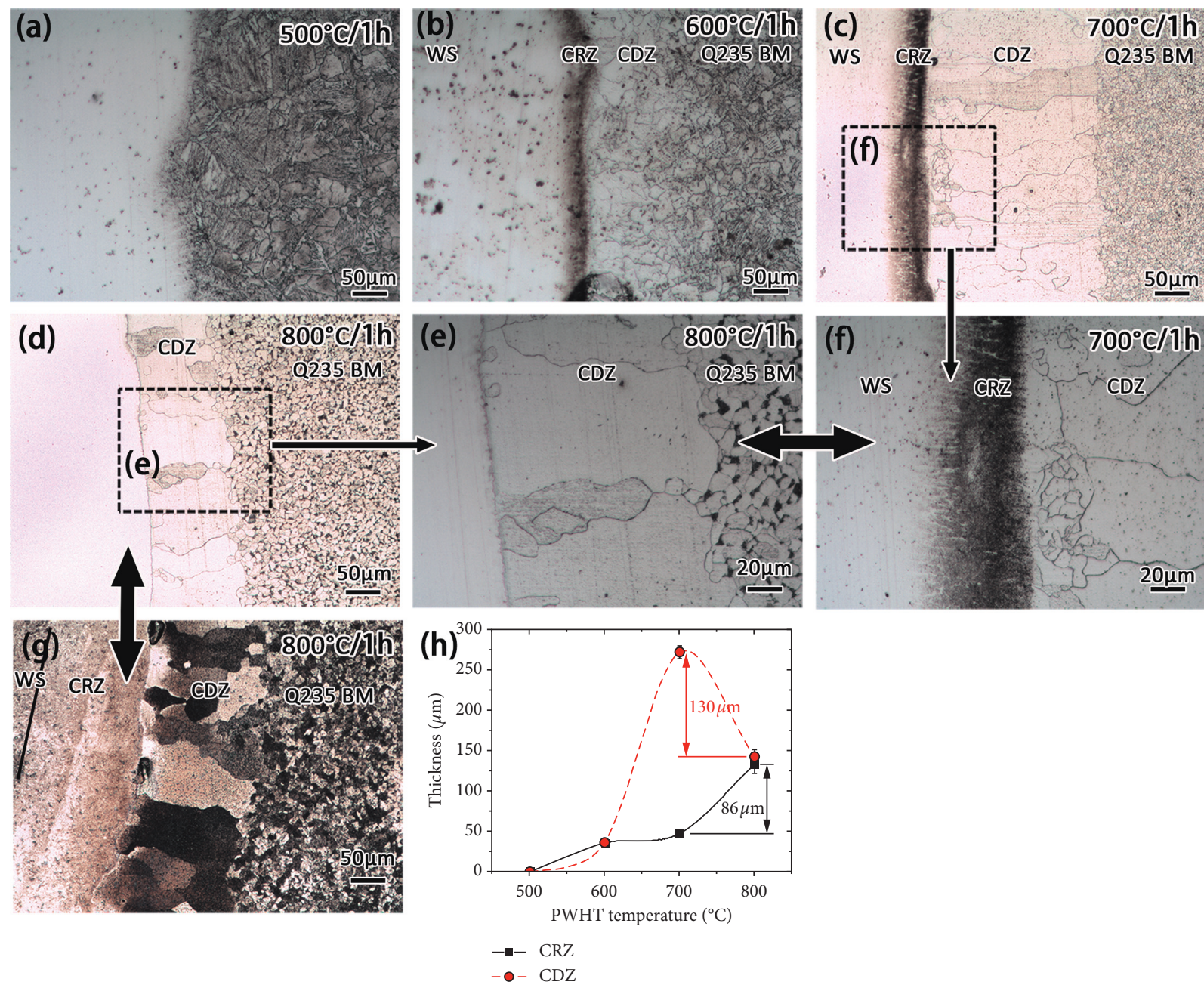

Figure 3: Microstructure of WS-Q235 interface and thickness of $\mathrm{CDZ}$ and CRZ: (a) heat-treated at $500^{\circ} \mathrm{C}$; (b) heat-treated at $600^{\circ} \mathrm{C}$; (c, f) heat-treated at $700^{\circ} \mathrm{C}$; (d, e, g) heat-treated at $800^{\circ} \mathrm{C}$; (h) thickness of $\mathrm{CDZ}$ and CRZ as a function of PWHT temperature.

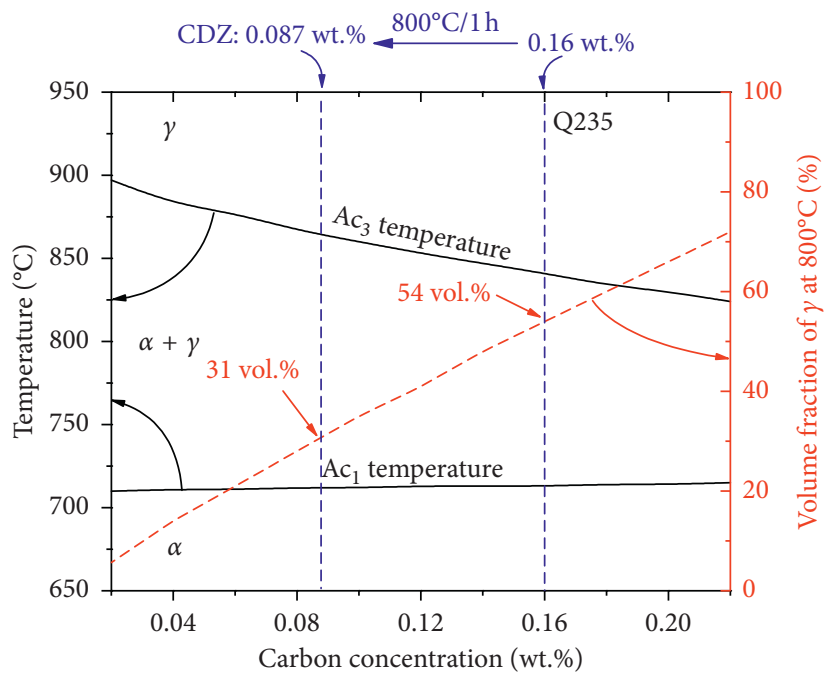

Figure 4: $\mathrm{Ac}_{1}$ temperature; $\mathrm{Ac}_{3}$ temperature; $\gamma$-Fe phase fraction of Q235 as a function of the carbon concentration. 

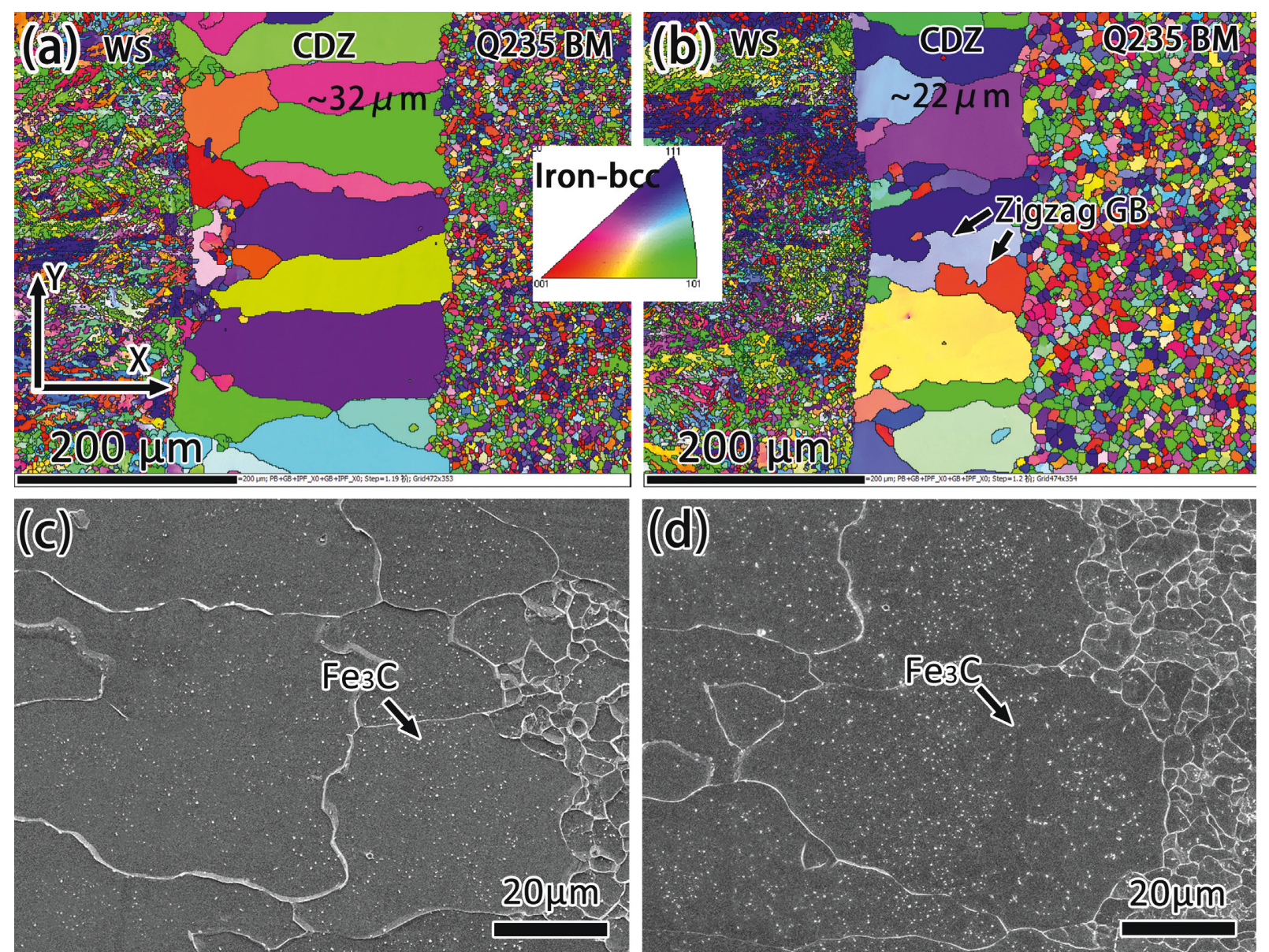

FIGURE 5: Microstructure of the CDZ; (a) grain orientation of the $\mathrm{CDZ}$ heat-treated at $700^{\circ} \mathrm{C}$; (b) grain orientation of the $\mathrm{CDZ}$ heat-treated at $800^{\circ} \mathrm{C}$; (c) $\mathrm{CDZ}$ heat-treated at $700^{\circ} \mathrm{C}$; (d) $\mathrm{CDZ}$ heat-treated at $800^{\circ} \mathrm{C}$.

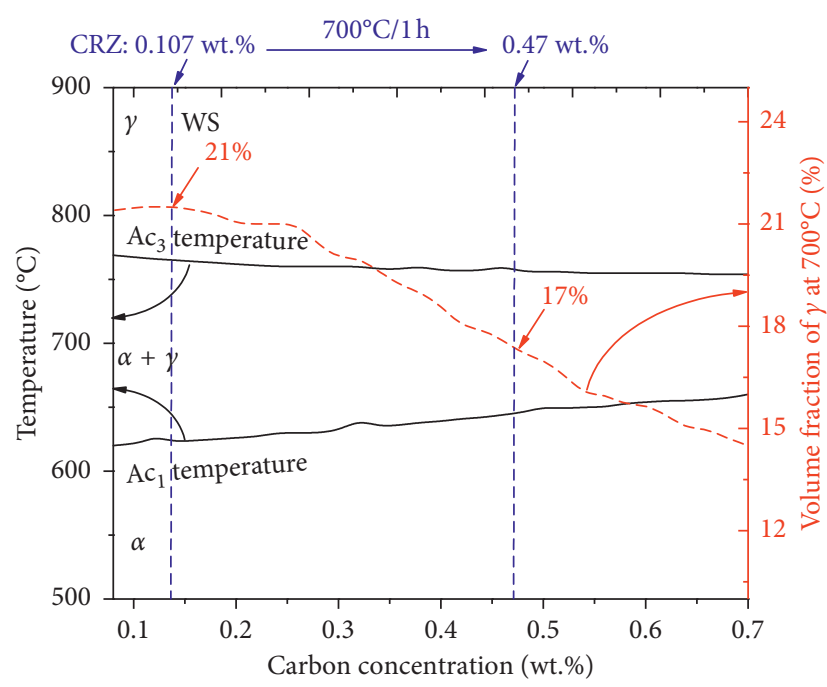

(a)

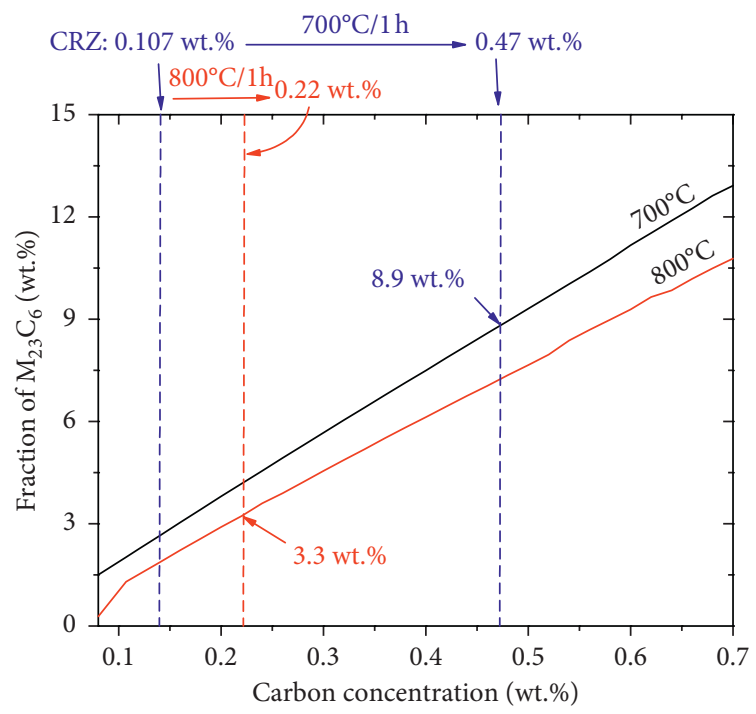

(b)

Figure 6: (a) $\mathrm{Ac}_{1}, \mathrm{Ac}_{3}$, and $\gamma$-Fe fraction as a function of carbon concentration; (b) $\mathrm{M}_{23} \mathrm{C}_{6}$ concentration as a function of carbon concentration. 
formation of $(\mathrm{Cr}, \mathrm{Fe})_{23} \mathrm{C}_{6}$ was similar to that at $600^{\circ} \mathrm{C}$. The untempered martensite came from the $\gamma$-Fe at $800^{\circ} \mathrm{C}$. When the joints heat-treated at $600^{\circ} \mathrm{C}$ and $700^{\circ} \mathrm{C}$ were etched by $\mathrm{HNO}_{3}\left(4\right.$ wt.\%) + ethanol solution, the $(\mathrm{Cr}, \mathrm{Fe})_{23} \mathrm{C}_{6}$ carbide was etched easily. Therefore, the CRZ could be observed clearly in Figures 3(b)-3(f).

The CRZ in the joint heat-treated at $800^{\circ} \mathrm{C}$ was of untempered martensite and small amount of $(\mathrm{Cr}, \mathrm{Fe})_{23} \mathrm{C}_{6}$ carbide. Therefore, it was hard to reveal the microstructure using $\mathrm{HNO}_{3}(4 \mathrm{wt} . \%)+$ ethanol as shown in Figures 3(e) and 3(f).

\subsection{Mechanical Properties after PWHT}

3.2.1. Hardness. The hardness distribution of the joints is shown in Figure 7(a). The hardness change of the 2205DSS and Q235 was small. In this investigation, the hardness evolution of 2205DSS BM and Q235 BM was not discussed as their small influence on the fracture behavior. The hardness evolution of WS, CRZ, and CDZ was discussed in detail. From Figures 7(a) and $7(\mathrm{~b})$, the hardness of the as-welded WS was approximately $550 \mathrm{HV}$. The hardness of the WS declined slightly after heattreated at $500^{\circ} \mathrm{C}$. When the WS was heat-treated at $600^{\circ} \mathrm{C}$ and $700^{\circ} \mathrm{C}$, the hardness was approximately $350 \mathrm{HV}$. When the PWHT temperature was increased to $800^{\circ} \mathrm{C}$, the hardness increased to approximately $450 \mathrm{HV}$. Moreover, the hardness of the WS near the WS/Q235 interface significantly increased (approximately $570 \mathrm{HV}$ ) as shown in Figure 7.

In this investigation, the hardness decline of WS at $500^{\circ} \mathrm{C}$, $600^{\circ} \mathrm{C}$, and $700^{\circ} \mathrm{C}$ should be attributed to the formation of tempered martensite. The hardness increase at $800^{\circ} \mathrm{C}$ should be attributed to the regain of untempered martensite.

The hardness distribution near the WS/Q235 interface is shown in Figure 7(b). The high-hardness CRZ in the joint heat-treated at $800^{\circ} \mathrm{C}$ should be attributed to the high-carbon martensite which had a high hardness as discussed in Section 3.1.4. However, the hardness increment of the CRZ in the joints heat-treated at $500^{\circ} \mathrm{C}, 600^{\circ} \mathrm{C}$, and $700^{\circ} \mathrm{C}$ was not observed in Figure $7(\mathrm{~b})$. Although $(\mathrm{Cr}, \mathrm{Fe}){ }_{23} \mathrm{C}_{6}$ carbide or small amount of untempered martensite generated in the $\mathrm{CRZ}$ in the joints heat-treated at $500^{\circ} \mathrm{C}, 600^{\circ} \mathrm{C}$, and $700^{\circ} \mathrm{C}$, its strengthening effect could not balance the hardness reduction of the tempered martensite at all. Therefore, the hardness of the CRZ did not increase after heat-treated at $500^{\circ} \mathrm{C}, 600^{\circ} \mathrm{C}$, and $700^{\circ} \mathrm{C}$.

The hardness of the $\mathrm{HAZ}$ heat-treated at $500^{\circ} \mathrm{C}$ declined slightly compared with that of the HAZ of the as-welded joint as shown in Figure 7(b). When the PWHT temperature was increased to $600^{\circ} \mathrm{C}$, the hardness of the $\mathrm{CDZ}$ was approximately $150 \mathrm{HV}$. The lowest hardness of the CDZ was only approximately $110 \mathrm{HV}$ after heat-treated at $700^{\circ} \mathrm{C}$. When heat-treated at $800^{\circ} \mathrm{C}$, the lowest hardness of the CDZ was improved to approximately $135 \mathrm{HV}$.

The low hardness of the CDZ in the joint heat-treated at $700^{\circ} \mathrm{C}$ and $800^{\circ} \mathrm{C}$ should be contributed to the less $\mathrm{Fe}_{3} \mathrm{C}$ particle and the coarse ferrite grain. The difference in $\mathrm{CDZ}$ hardness between the two joints should also be discussed. From the discussion about the $\mathrm{Fe}_{3} \mathrm{C}$ in Section 3.1.3, the

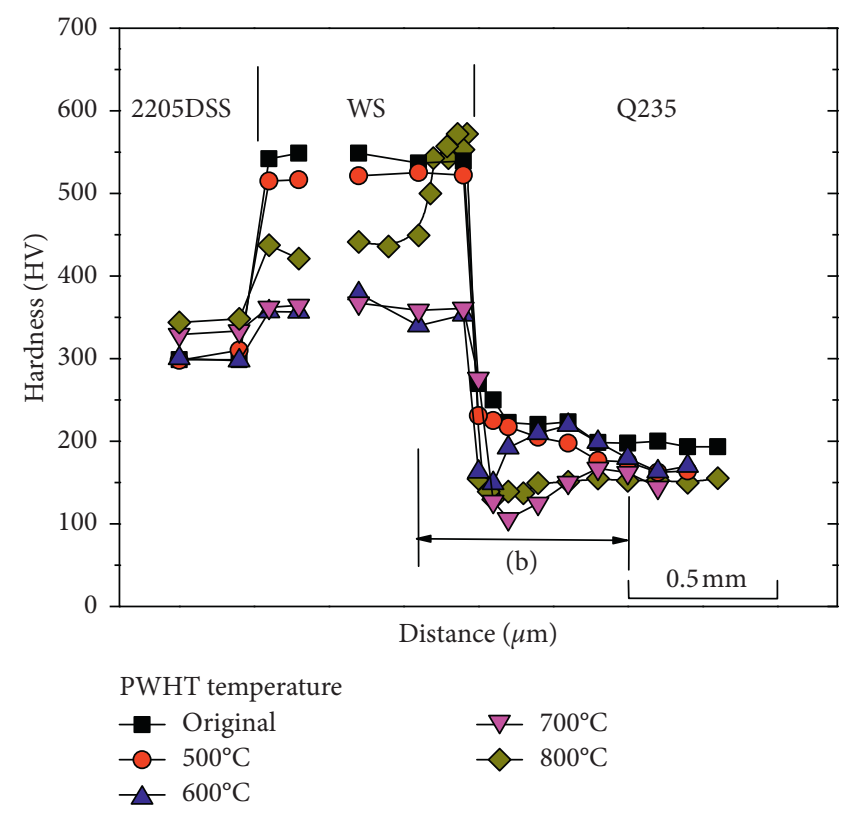

(a)

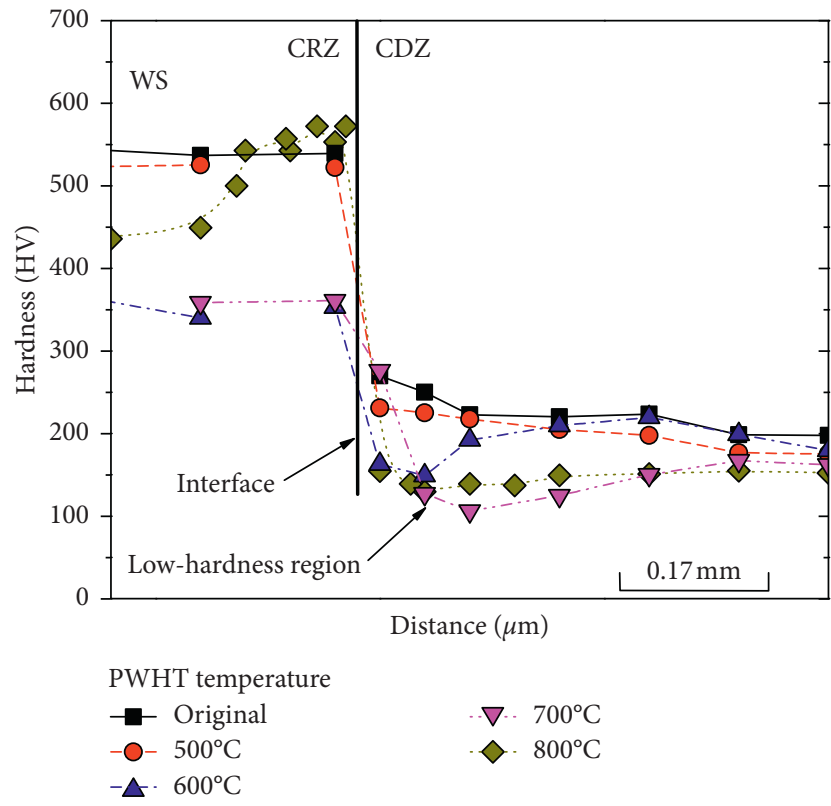

(b)

FIGURE 7: Hardness distribution of the as-welded and heat-treated 2205DSS-Q235 joints: (a) the whole joint; (b) the WS-Q235 interface.

fraction of $\mathrm{Fe}_{3} \mathrm{C}$ in the $\mathrm{CDZ}$ heat-treated at $700^{\circ} \mathrm{C}$ was smaller than that heat-treated at $800^{\circ} \mathrm{C}$. Moreover, the grain sizes of the $\mathrm{CDZ}$ in the joints heat-treated at $700^{\circ} \mathrm{C}$ and $800^{\circ} \mathrm{C}$ were $\sim 32 \mu \mathrm{m}$ and $\sim 22 \mu \mathrm{m}$ from the EBSD results. Therefore, the coarse grain and less $\mathrm{Fe}_{3} \mathrm{C}$ of $\mathrm{CDZ}$ in the joint heat-treated at $700^{\circ} \mathrm{C}$ contributed to its lowest hardness.

3.2.2. Strength, Elongation, and Fracture Behavior. The stress-strain curves are shown in Figure 8(a). The 


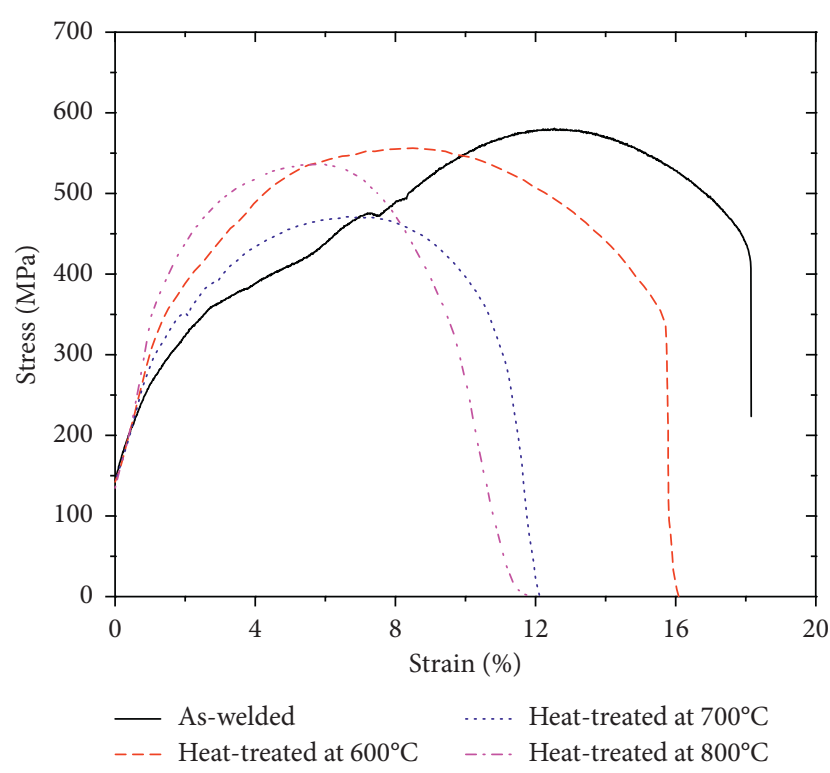

(a)

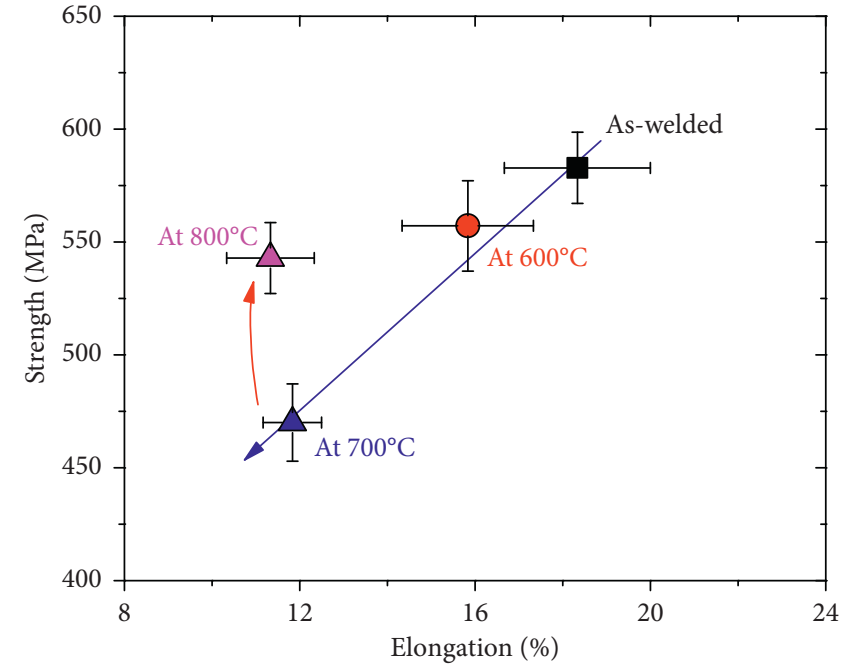

(b)

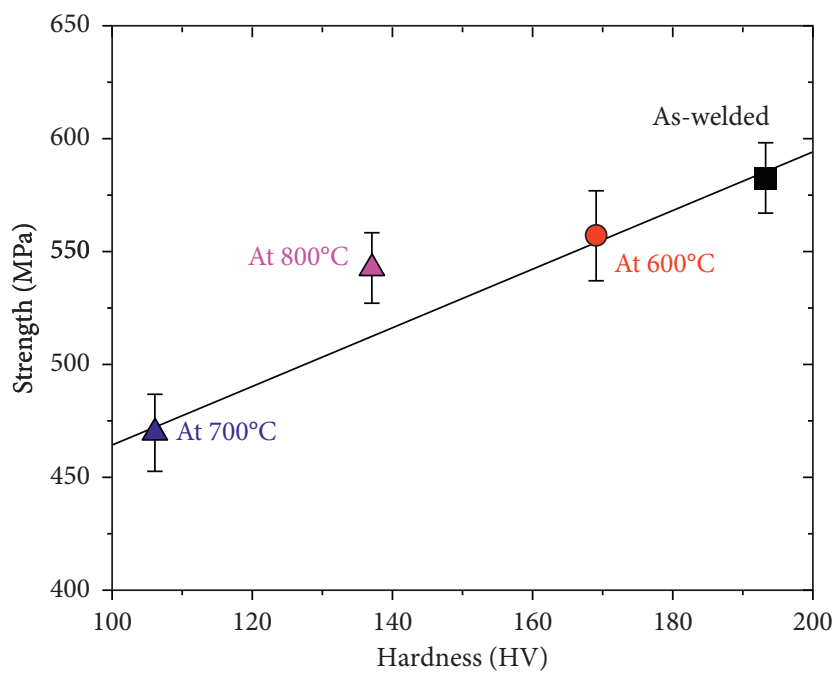

(c)

FIGURE 8: (a) Stress-strain curves; (b) strength vs. elongation; (c) strength vs. hardness.

strength as a function of elongation is shown in Figure 8 (b). It was found that all of the strength and elongation gradually declined as the increase of PWHT temperature when the PWHT temperature was below $700^{\circ} \mathrm{C}$. However, when the PWHT temperature was $800^{\circ} \mathrm{C}$, the strength increased.

The microstructure of the cross section of fractured joints is shown in Figure 9. From Figures 9(a) and 9(b), the fracture location of the joints without PWHT and heattreated at $600^{\circ} \mathrm{C}$ was in the Q235 $\mathrm{BM}$. The fracture of the joints heat-treated at $700^{\circ} \mathrm{C}$ and $800^{\circ} \mathrm{C}$ was located in the $\mathrm{CDZ}$ as shown in Figures $9(\mathrm{c})-9(\mathrm{~h})$. In this paper, the relationship between hardness of the fractured zone and strength of the joints was investigated as shown in Figure $8(\mathrm{c})$. It could be found that the strength of the joint was mainly determined by the hardness of the fracture zone.
From Figures 9(c) and 9(d), the CDZ in the joints heattreated at $700^{\circ} \mathrm{C}$ and $800^{\circ} \mathrm{C}$ induced the fracture during tensile. However, the $\mathrm{CDZ}$ in the joint heat-treated at $600^{\circ} \mathrm{C}$ could not result in the fracture as shown in Figure 9(b). It should be attributed to the small thickness of the $\mathrm{CDZ}$ in the joint heat-treated at $600^{\circ} \mathrm{C}$. During tensile, the strength of the WS and the Q235 near the CDZ in the joint heat-treated at $600^{\circ} \mathrm{C}$ was higher than the thin $\mathrm{CDZ}$. The deformation of the $\mathrm{CDZ}$ was restricted. Therefore, the necking did not occur in the CDZ. On the contrary, the Q235 BM was stretched. When the true stress of the Q235 BM increased to a critical value, the necking occurred in the Q235 BM. Therefore, the fracture was located in the Q235 BM.

The plastic deformation of the Q235 BM contributed to the higher elongation of the joints without PWHT and heattreated at $600^{\circ} \mathrm{C}$. With regard to the joints heat-treated at $700^{\circ} \mathrm{C}$ and $800^{\circ} \mathrm{C}$, the necking and fracture rapidly 


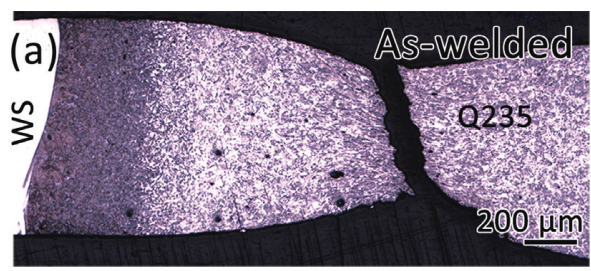

(a)

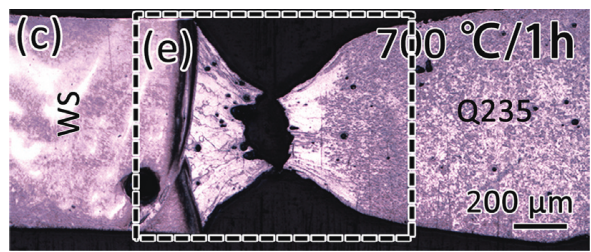

(c)

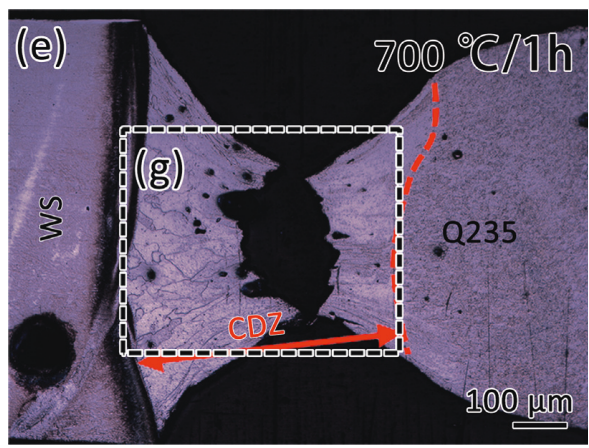

(e)

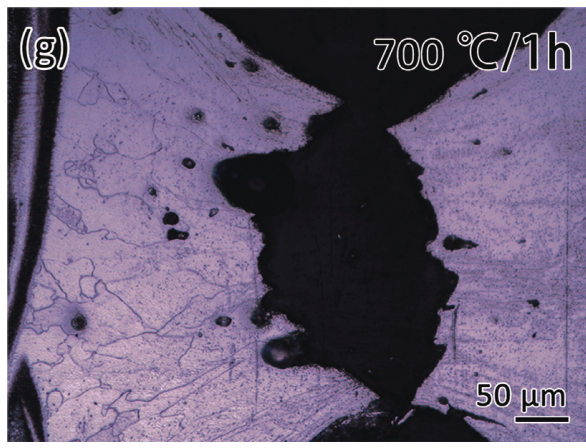

(g)

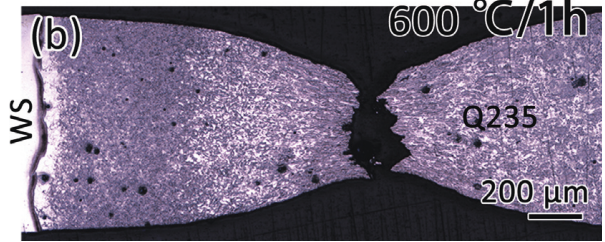

(b)

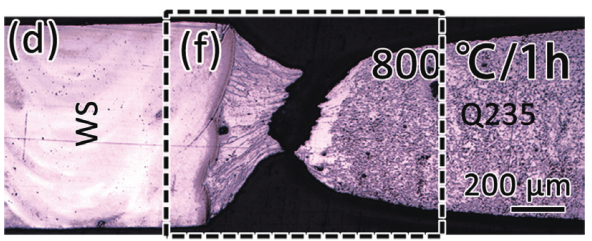

(d)

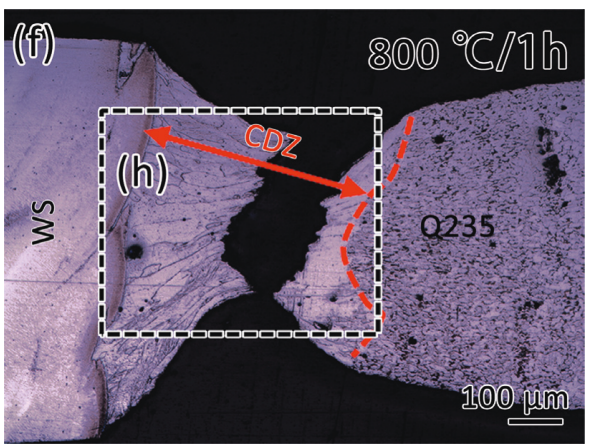

(f)

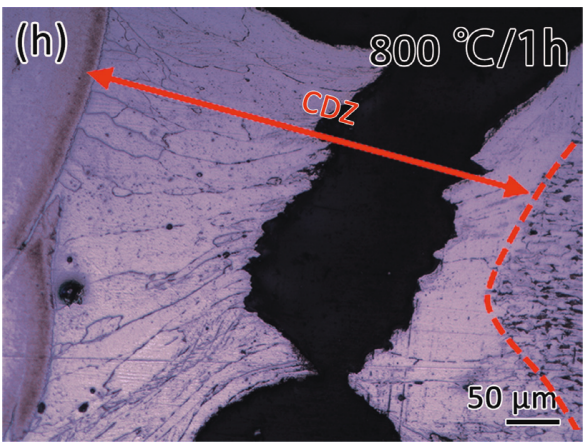

(h)

Figure 9: (a) Fractured as-welded joint; (b) fractured joint heat-treated at $600^{\circ} \mathrm{C}$; (c, e, g) fractured joint heat-treated at $700^{\circ} \mathrm{C}$; $(\mathrm{d}, \mathrm{f}, \mathrm{h})$ fractured joint heat-treated at $800^{\circ} \mathrm{C}$.

generated in the CDZ during tensile. The deformation of the Q235 BM was small. Therefore, the elongation of the joints heat-treated at $700^{\circ} \mathrm{C}$ and $800^{\circ} \mathrm{C}$ was small as shown in Figures $8(\mathrm{a})$ and $8(\mathrm{~b})$.

\section{Conclusions}

(1) Tempered martensite was obtained in the WS when heat-treated at $500^{\circ} \mathrm{C}$ and $600^{\circ} \mathrm{C}$, as the generation of precipitates and decline of dislocation density. Untempered martensite was retained in the WS when heat-treated at $800^{\circ} \mathrm{C}$ which was higher than the $\mathrm{Ac}_{3}$ temperature.
(2) The CDZ and CRZ were generated on the WS/Q235 interface after heat-treated at $600^{\circ} \mathrm{C}, 700^{\circ} \mathrm{C}$, and $800^{\circ} \mathrm{C}$, as the carbon atoms diffused from Q235 BM to WS. The $\mathrm{CDZ}$ of the joint heat-treated at $800^{\circ} \mathrm{C}$ was thinner than that heat-treated at $700^{\circ} \mathrm{C}$ because of the generation of $\gamma$-Fe in Q235 BM during heat-treatment.

(3) The hardness of the WS declined to $\sim 350 \mathrm{HV}$ after heat-treated at $600^{\circ} \mathrm{C}$ and $700^{\circ} \mathrm{C}$ as the tempered martensite formed. The hardness of the WS heattreated at $800^{\circ} \mathrm{C}$ was $\sim 450 \mathrm{HV}$ as the untempered martensite was retained.

(4) The softening was found in the CDZ. Only the CRZ of the joint heat-treated at $800^{\circ} \mathrm{C}$ was hardened as 
high-carbon untempered martensite was generated which had a hardness of $\sim 570 \mathrm{HV}$.

(4) The strength of the joint was roughly determined by the hardness of the fracture zone. The CDZ in joints heat-treated at $700^{\circ} \mathrm{C}$ and $800^{\circ} \mathrm{C}$ contributed to the tensile fracture of the joints. The joint fractured in the CDZ exhibited the lower elongation.

\section{Data Availability}

All the data in the article came from our experiments.

\section{Conflicts of Interest}

The authors declare that they have no conflicts of interest.

\section{References}

[1] C. Pandey, M. M. Mahapatra, P. Kumar, and N. Saini, "Comparative study of autogenous tungsten inert gas welding and tungsten arc welding with filler wire for dissimilar P91 and P92 steel weld joint," Materials Science and Engineering A, vol. 712, no. 17, pp. 720-737, 2018.

[2] R. S. Vidyarthy, A. Kulkarni, and D. K. Dwivedi, "Study of microstructure and mechanical property relationships of A-TIG welded P91-316L dissimilar steel joint," Materials Science and Engineering A, vol. 695, no. 17, pp. 249-257, 2017.

[3] L. Falat, J. Kepic, L. Ciripová, P. Ševc, and I. Dlouhý, "The effects of postweld heat treatment and isothermal aging on T92 steel heat-affected zone mechanical properties of T92/ TP316H dissimilar weldments," Journal of Materials Research, vol. 31, no. 10, pp. 1532-1543, 2016.

[4] G. Li, X. Lu, X. Zhu, J. Huang, L. Liu, and Y. Wu, "The interface microstructure, mechanical properties and corrosion resistance of dissimilar joints during multipass laser welding for nuclear power plants," Optics and Laser Technology, vol. 101, pp. 479-490, 2018.

[5] P. Prabaharan, K. Devendranath Ramkumar, and N. Arivazhagan, "Characterization of microstructure and mechanical properties of Super Ni 718 alloy and AISI 316L dissimilar weldments," Journal of Materials Research, vol. 29, no. 24, pp. 3011-3023, 2014.

[6] F. Mas, C. Tassin, N. Valle et al., "Metallurgical characterization of coupled carbon diffusion and precipitation in dissimilar steel welds," Journal of Materials Science, vol. 51, no. 10, pp. 4864-4879, 2016.

[7] F. Mas, C. Tassin, F. Roch, M. Yescas, P. Todeschini, and Y. Brechet, "Growth morphologies and primary solidification modes in a dissimilar weld between a low-alloy steel and an austenitic stainless steel," Metals, vol. 8, no. 4, pp. 284-305, 2018.

[8] R. Anand, C. Sudha, T. Karthikeyan, A. L. E. Terrance, S. Saroja, and M. Vijayalakshmi, "Effectiveness of Ni-based diffusion barriers in preventing hard zone formation in ferritic steel joints," Journal of Materials Science, vol. 44, no. 1, pp. 257-265, 2008.

[9] H. Ming, R. Zhu, Z. Zhang et al., "Microstructure, local mechanical properties and stress corrosion cracking susceptibility of an SA508-52M-316LN safe-end dissimilar metal weld joint by GTAW," Materials Science and Engineering A, vol. 669, no. 4, pp. 279-290, 2016.
[10] T. Sarikka, M. Ahonen, R. Mouginot et al., "Effect of mechanical mismatch on fracture mechanical behavior of SA 508 - alloy 52 narrow gap dissimilar metal weld," International Journal of Pressure Vessels and Piping, vol. 157, pp. 30-42, 2017.

[11] Q. Wu, F. Lu, H. Cui, X. Liu, P. Wang, and Y. Gao, "Soft zone formation by carbon migration and its effect on the high-cycle fatigue in $9 \% \mathrm{Cr}-\mathrm{CrMoV}$ dissimilar welded joint," Materials Letters, vol. 141, no. 15, pp. 242-244, 2015.

[12] M. Li, Z. Li, Y. Zhao, H. Li, Y. Wang, and J. Huang, "Influence of welding parameters on weld formation and microstructure of dual-laser beams welded T-joint of aluminum alloy," Advances in Materials Science and Engineering, vol. 2011, Article ID 767260, 6 pages, 2011.

[13] A. Elbatahgy and M. Kutsuna, "Laser beam welding of AA5052, AA 5083, and AA 6061 aluminum alloys," Advances in Materials Science and Engineering, vol. 2009, Article ID 974182, 9 pages, 2009.

[14] M. Behúlová, E. Babalová, and M. Sahul, "Design of laser welding parameters for joining Ti grade 2 and AW 5754 aluminium alloys using numerical simulation," Advances in Materials Science and Engineering, vol. 2017, Article ID 3451289, 15 pages, 2017.

[15] L. Commin, M. Dumont, R. Rotinat, F. Pierron, J. E. Masse, and L. Barrallier, "Texture evolution in Nd:YAG-laser welds of AZ31 magnesium alloy hot rolled sheets and its influence on mechanical properties," Materials Science and Engineering A, vol. 528, no. 4-5, pp. 2049-2055, 2011.

[16] G. Padmanaban and V. Balasubramanian, "Fatigue performance of pulsed current gas tungsten arc, friction stir and laser beam welded AZ31B magnesium alloy joints," Materials and Design, vol. 31, pp. 3724-3732, 2010.

[17] W. W. Zhang, S. Cong, S. B. Luo, and J. H. Fang, "Effects of energy density and shielding medium on performance of laser beam welding (LBW) joints on SAF2205 duplex stainless steel," JOM, vol. 70, pp. 1554-1559, 2018.

[18] J. Xu, J. Chen, Y. Duan, C. Yu, J. Chen, and H. Lu, "Comparison of residual stress induced by TIG and LBW in girth weld of AISI 304 stainless steel pipes," Journal of Materials Processing Technology, vol. 248, pp. 178-184, 2017.

[19] C. Du, X. Wang, and L. Hu, "Microstructure, mechanical properties and residual stress of a 2205DSS/Q235 rapidly formed LBW joint," Journal of Materials Processing Technology, vol. 256, pp. 78-86, 2018.

[20] C. Du, X. Wang, and C. Luo, "Effect of post-weld heat treatment on the microstructure and mechanical properties of the 2205DSS/Q235 laser beam welding joint," Journal of Materials Processing Technology, vol. 263, pp. 138-150, 2019.

[21] M. Huang and L. Wang, "Carbon migration in $5 \mathrm{Cr}-0.5 \mathrm{Mo} /$ 21Cr-12Ni dissimilar metal welds," Metallurgical and Materials Transactions A, vol. 29, no. 12, pp. 3037-3046, 1998. 


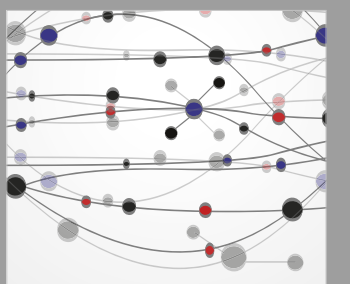

The Scientific World Journal
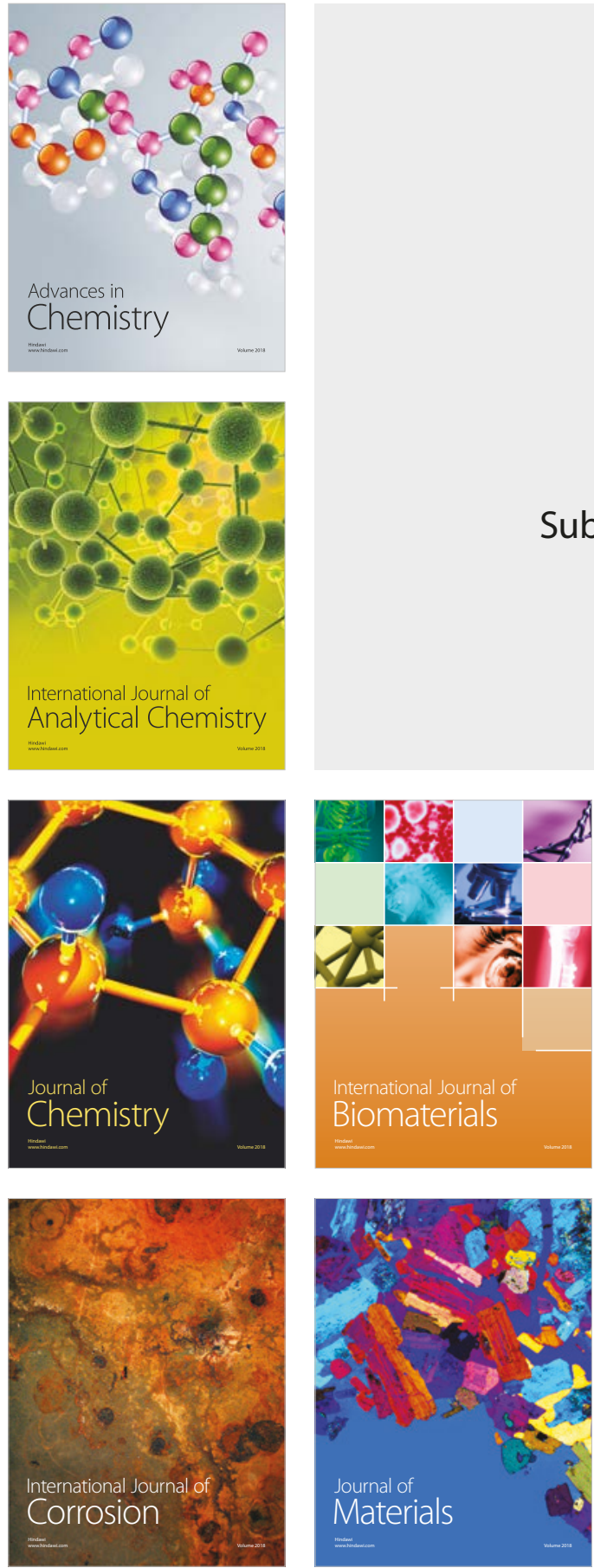

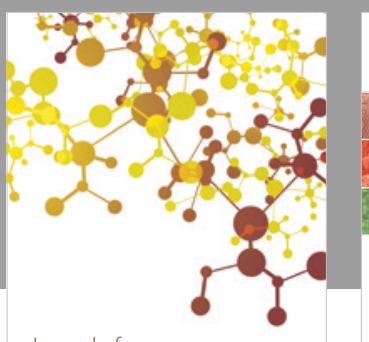

Journal of

Applied Chemistry
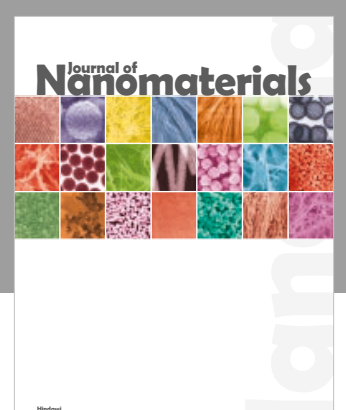

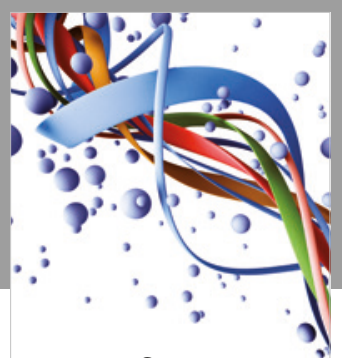

Scientifica

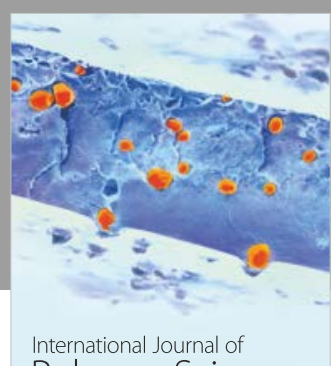

Polymer Science

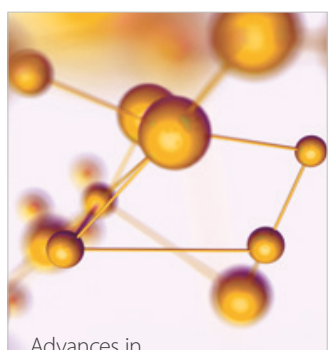

Physical Chemistry
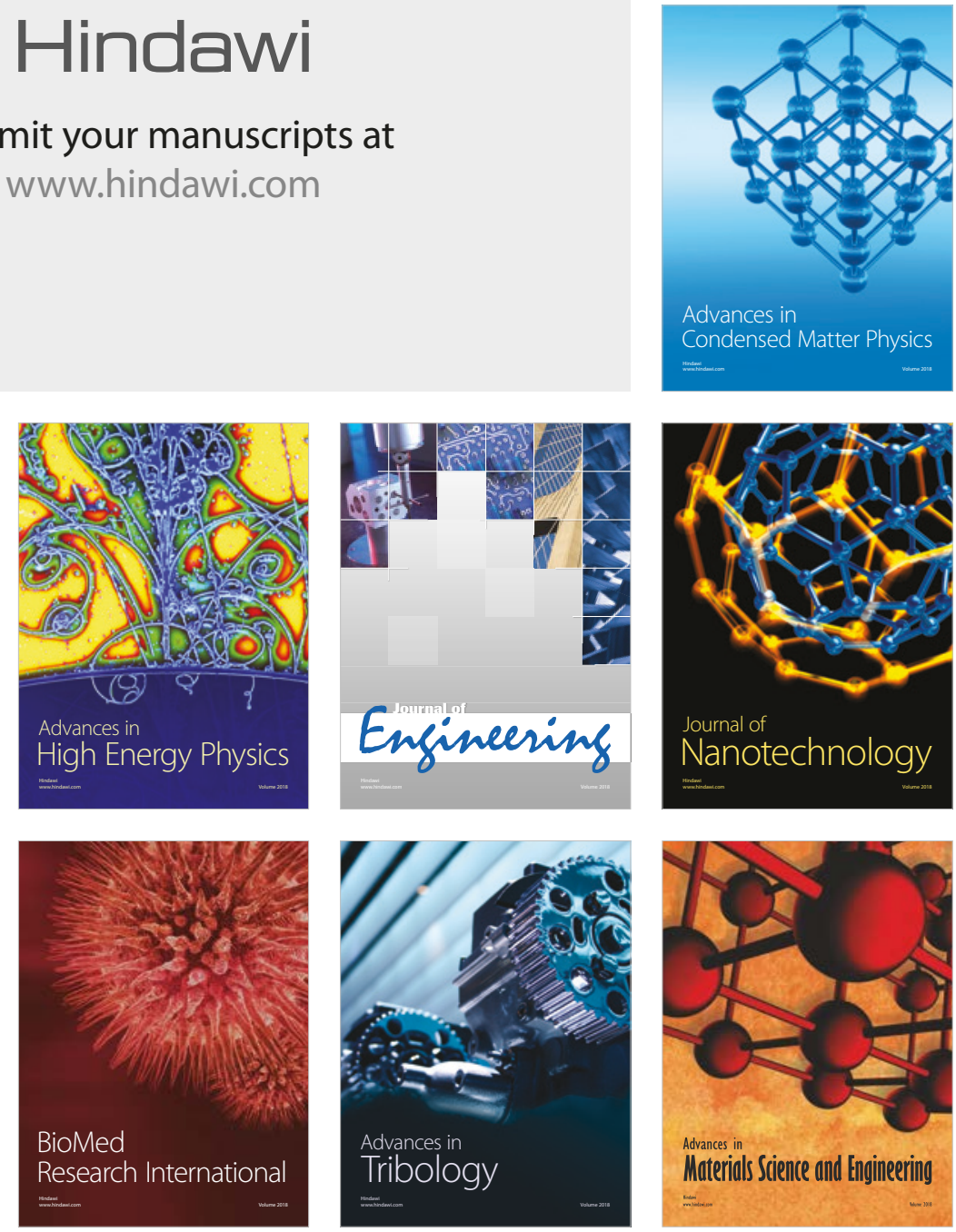